\title{
Desarrollo de un nuevo sistema de material compuesto: resistente al fuego y altamente estructural
}

\section{Development of a new composite system: fire resistant and highly structural}

\author{
J. González ${ }^{(*)}, \underline{\text { D. Ranz }}{ }^{(* *)}$, J. A. Márquez(*), A. Miravete(***)
}

Recepción/Received: 4-IV-08

Aceptación/Accepted: 10-II-09

Publicado online/Online publishing: $24-\mathrm{V}-10$

RESUMEN

Los sectores de la construcción y del ferrocarril tienen dos aspectos en común en el ámbito de los materiales: la utilización de materiales altamente estructurales y la aplicación de estrictos requerimientos de fuego. Asimismo, en ambos sectores existe un interés creciente en el uso de materiales compuestos de matriz orgánica por sus excelentes prestaciones, ligereza y comportamiento en servicio. Tradicionalmente, se han aplicado cargas anti-fuego a la matriz orgánica, disminuyendo sus propiedades mecánicas de forma importante.

En este artículo se presentará un estudio de materiales compuestos formados por tres matrices orgánicas diferentes y cuatro tipos de fibras de carbono. Con estos constituyentes se han fabricado diferentes laminados para analizar, por un lado, la procesabilidad de estas resinas, y, por otro, la compatibilidad de estas resinas con las fibras de refuerzo utilizadas. Este estudio es necesario debido a que al tratarse de resinas formuladas con características frente a fuego y humos, su fabricabilidad puede presentar problemas más complejos que en las resinas convencionales.

Palabras clave: materiales compuestos, propiedades mecanicas, resistencia a tracción, resistencia a fuego y humos.

\section{SUMMARY}

Infrastructure and rail sectors share two singularities in terms of materials: highly structural performance and strict fire requirements. Moreover, there is a common growing interest in both sectors: the use of organic matrix composite materials due to their high performance, lightweight and in-service behavior. Traditionally, fire fillers have been added to the matrix, decreasing its mechanical performance in a critical way.

A study about composite materials formed by three different matrices and four different carbon fibers will be presented in this paper. A number of laminates have been manufactured by using these composite materials in order to analyze both the resin processing and the compatibility of the different matrices and fibers. This study is a need due to the fact that these matrices are fire-related and therefore further problems may arise in comparison with standard matrices.

Keywords: composites, mechanical properties, tensile strength, fire and smoke resistance.

(*) Metro de Madrid (Madrid, España).

(**) Sistemas y Procesos Avanzados (Zaragoza, España).

(***) Universidad de Zaragoza (Zaragoza, España). 


\section{INTRODUCCIÓN}

Para la preparación de este trabajo, se estudiaron inicialmente matrices de poliéster, epoxi y fenólicas. Los materiales compuestos fabricados con resinas fenólicas mantienen sus propiedades mecánicas a temperaturas mucho más elevadas que lo que lo hacen aquéllos que comúnmente utilizan otras matrices termoestables (1-10).

En ambientes a alta temperatura, las resinas fenólicas mantienen la mayor parte de su resistencia hasta los $200{ }^{\circ} \mathrm{C}$, aunque se admiten picos puntuales de hasta $300{ }^{\circ} \mathrm{C}$. Sin embargo las propiedades mecánicas de otras matrices alternativas se deterioran rápidamente entre los 75 y $125^{\circ} \mathrm{C}$. Por otra parte, las propiedades mecánicas de los materiales compuestos con matriz fenólica a temperatura ambiente, en general, son más bajas que los de epoxi.

A la hora de seleccionar los tres tipos de matrices, objeto de estudio de este trabajo, se ha tenido en cuenta en primer lugar que cumplieran los requerimientos mínimos a fuego y humos establecidos por la normativa (M1, F1, según norma NF F 16-101). Respecto al proceso se ha elegido infusión, uno - dentro de las tecnologías- de los más prometedores y eficientes en coste para materiales compuestos de matriz orgánica.

Existe una resina de la empresa Ashland, denominada Modar 835 S, que junto a cargas de ATH (Trihidrato de alúmina) presenta buenas propiedades frente a fuego, pero se debe de procesar en un molde cerrado, para evitar la evaporación de un acrilato que es utilizado como disolvente, sin el cual las reacciones de polimerización no se completan. También la marca DSM-BASF presenta dos resinas de poliéster, con el nombre comercial Synolite, que cargadas con ATH ofrecen unas excelentes propiedades frente a fuego (M1, F0, según norma NF F 16-101). El problema que presenta esta gama de resinas es el alto nivel de cargas retardantes de fuego que contienen, que va a implicar que las propiedades mecánicas finales sean muy pobres.

En cuanto a las resinas epoxi, se han estudiado varias de ese tipo que han sido formuladas para exhibir un buen comportamiento frente a fuego. Estas resinas, a pesar de no llegar a cumplir individualmente los estrictos requerimientos de fuego exigidos, pueden llegar a hacerlo cuando forman parte de un conjunto de panel sándwich. Este motivo, junto a que son resinas que presentan unas excelentes propiedades mecánicas, hace que sean unos buenos candidatos para ser un material constituyente de perfiles de refuerzo embebido en paneles sándwich.

\section{INTRODUCTION}

Along this work, polyester, epoxy and phenolic resin were analyzed. Phenolic matrix composite materials are stronger at higher temperatures that any other thermoset matrices (1-10).

At higher temperatures, phenolic matrices maintain their mechanical properties up to $200{ }^{\circ} \mathrm{C}$, though they can support peak stresses up to $300^{\circ} \mathrm{C}$. However, other thermoset matrices rapidly deteriorate between 75 and $125^{\circ} \mathrm{C}$. At room temperature, phenolic matrix composite materials present lower mechanical properties than epoxies.

When selecting the matrices along this work, M1, F1, fire and smoke requirements, according to NF F 16-101, were taking account. Infusion manufacturing processing -one of the most promising organic matrix composites processes- was used to obtain coupons for the current experimental study.

Modar 835 S epoxy resin from Ashland along with aluminum tri-hydrate (ATH) fillers presents good fire behavior, but closed mold processing must be used due to solvent evaporation phenomenon. DSM-BASF commercializes two polyester resins with the trademark of Synolite, which combined with ATH present outstanding fire/smoke properties (M1, FO, according to NF F 16-101). The drawback of these resins is that these fillers considerable reduces their mechanical performance.

Epoxy resins are more difficult to formulate than phenolic or polyester to meet the mentioned fire/smoke requirements. However, epoxy resins accomplish with M1, F0, according to NF F 16-101, when they are a part of a sandwich configuration. Therefore this type of resin is a good option for a sandwich subjected to fire/smoke requirements due to their high mechanical performance. 
Por otro lado, es bien conocido el excelente comportamiento frente a fuego de las resinas fenólicas. No así tanto la compatibilidad y adherencia con los refuerzos que se van a utilizar y su procesabilidad, por ello van a ser necesarios los ensayos mecánicos y de proceso que se van a llevar a cabo (11-33).

\section{DESCRIPCIÓN DE LAS FIBRAS Y MATRICES UTILIZADAS}

Entre todas las resinas estudiadas, hemos visto que ninguna de las poliésteres analizadas puede llegar a cumplir simultáneamente los tres requerimientos exigidos de fuego, proceso y propiedades mecánicas. Por tanto, se ha optado por realizar las pruebas de procesabilidad y de determinación de las propiedades mecánicas sobre laminados realizados con dos resinas epoxi, Epolam 2500 y Bepox 1622 y con la resina fenólica Cellobond J2027L. La resina fenólica no sólo presenta un buen comportamiento en cuanto a reacción a fuego y emisión de humos, sino que además mantiene sus propiedades mecánicas a mayores temperaturas que las resinas convencionales. Las propiedades de las tres matrices orgánicas estudiadas se representan en la Tabla 1.
On the other hand, it is well known that phenolic resins present an outstanding fire behavior. Matrix compatibility and adherence to reinforcements -two weak aspects of phenolic matrix composite materials- will also be analyzed along this paper by means of an experimental study (11-33).

\section{DESCRIPTION OF FIBERS AND MATRICES USED IN THIS STUDY}

Due to the lower mechanical properties of polyester resins, none of the polyester systems analyzed meet the three requirements needed and therefore, both epoxy and phenolic resins have been analyzed in terms of processing and mechanical behavior. Epoxies Epolam 2500 y Bepox 1622 and phenolic Cellobond J2027L are the trademarks of the three resins studied (Table 1). The phenolic resin analyzed not only meets the fire and smoke requirements, but also presents good mechanical properties at high temperatures.

Tabla 1 / Table 1

Propiedades de las resinas seleccionadas.

Properties of the three resins selected.

\begin{tabular}{|c|c|c|c|c|c|c|}
\hline Resina / Resin & Marca / Trade & $\begin{array}{l}\text { Designación / } \\
\text { Designation }\end{array}$ & $\begin{array}{c}\text { Características I } \\
\text { Characteristics }\end{array}$ & Curado / Cure & Pot life & $\begin{array}{c}\text { Comportamiento a fuego / } \\
\text { Fire Behavior }\end{array}$ \\
\hline Epoxi & Gairesa & Bepox 1622 & $\begin{array}{c}\text { Bicomponente } \\
(2.38 / 1) / \\
\text { Biocomponent } \\
(2.38 / 1)\end{array}$ & $\begin{array}{c}\mathrm{T}^{\mathrm{a}} \text { amb. + Postcurado } \\
\text { a } 80^{\circ} \mathrm{C} / \mathrm{RT}+ \\
\text { Postcure at } 80^{\circ} \mathrm{C}\end{array}$ & $5 \mathrm{~h}$ & $\begin{array}{c}\text { Junto Gel-Coat / UIT Gel-Coat } \\
\text { Bepox1643 (B0, s1) }\end{array}$ \\
\hline Epoxi & Axon & Epolam 2500 & $\begin{array}{l}\text { Bicomponente } \\
(100 / 22) / \\
\text { Biocomponent } \\
(100 / 22)\end{array}$ & $\begin{array}{c}\text { Ta amb. + Postcurado } \\
\text { a } 1000^{\circ} \mathrm{C} / R T+ \\
\text { Postcure at } \\
100^{\circ} \mathrm{C}\end{array}$ & $80 \mathrm{~m}$ & $\begin{array}{l}\text { Autoextinguible / } \\
\text { Self-extinguishable } \\
\text { (FAR25) }\end{array}$ \\
\hline $\begin{array}{l}\text { Fenólica / } \\
\text { Phenolics }\end{array}$ & Borden & Cellobond J2027L & $\begin{array}{c}\text { Catalizador } \\
\text { Phencat } 382 \text { / } \\
\text { Catalist } \\
\text { Phencat } 382\end{array}$ & $70-80^{\circ} \mathrm{C}$. & $25 \mathrm{~m}-8 \mathrm{~h}$ & $\begin{array}{l}\text { M1 F1 } \\
\text { (Normativa francesa) / } \\
\text { French regulations }\end{array}$ \\
\hline
\end{tabular}

En cuanto a los refuerzos empleados en estos laminados, se han seleccionado cuatro tejidos unidireccionales de fibra de carbono (Tabla 2).

Se han fabricado laminados combinando cada uno de los refuerzos con cada una de las resinas, para analizar, por un lado, la procesabilidad de estas resinas, y, por otro, mediante la realización de ensayos mecánicos conoceremos las propiedades del material compuesto y la compatibilidad de estas resinas con las fibras de refuerzo.
Four unidirectional carbon reinforcements have been studied (Table 2).

Processing and experimental mechanical properties of the twelve combinations (3 resins and 4 carbon reinforcement) will be described in the following sections. On the one hand, the resin processability will be studied. On the other hand, by means of the mechanical tests, both compatibility of these resins with the reinforcements and composite material mechanical properties will be assessed. 
Tabla 2 / Table 2

Propiedades de los refuerzos seleccionados. Properties of the tour carbon reinforcements selected.

\begin{tabular}{|c|c|c|c|c|c|}
\hline Refuerzo / Fiber & Marca / Trade & $\begin{array}{c}\text { Designación / } \\
\text { Designation }\end{array}$ & $\begin{array}{c}\text { Características / } \\
\text { Characteristics }\end{array}$ & $\begin{array}{c}\text { Módulo / Modulus } \\
\text { (GPa) }\end{array}$ & $\begin{array}{c}\text { Resistencia / } \\
\text { Strength (MPa) }\end{array}$ \\
\hline Carbono / Carbon & Zoltek & PX35FBUD0300 & $\begin{array}{c}\text { Unidireccional / Unidirectional, } \\
300 \mathrm{gr} / \mathrm{m}^{2}\end{array}$ & 242 & 3800 \\
\hline Carbono / Carbon & Hexcel & UD 250 & $\begin{array}{c}\text { Unidireccional / Unidirectional, } \\
225 \mathrm{gr} / \mathrm{m}^{2}\end{array}$ & 250 & 3900 \\
\hline Carbono / Carbon & ECC MM & UD 45002 & $\begin{array}{c}\text { Unidireccional / Unidirectional, } \\
500 \mathrm{gr} / \mathrm{m}^{2}\end{array}$ & 238 & 3950 \\
\hline Carbono / Carbon & ECC AM & UD 82502 & $\begin{array}{c}\text { Unidireccional HM / Unidireccional } \\
\text { HM, } 250 \mathrm{gr} / \mathrm{m}^{2}\end{array}$ & 640 & 2600 \\
\hline
\end{tabular}

Además, al tener todos estos laminados, tenemos la posibilidad de comparar una resina, la fenólica, cuyo comportamiento a fuego es muy bueno, pero de la que mecánicamente no se tiene tanto conocimiento como de las resinas epoxi, de las cuales se tiene una mayor experiencia.

\section{DESCRIPCIÓN DEL PROCESO DE FABRICACIÓN DE LAS PROBETAS}

Para la realización de los laminados se va a utilizar el proceso de infusión, que consiste en la impregnación manual de los tejidos secos y su posterior compactación por el efecto de la bolsa de vacío. Es un proceso de molde abierto en el que sólo sobre una de las caras puede conseguirse un buen acabado superficial.

El método operativo consta de las siguientes fases: preparación del molde, preparación del refuerzo, preparación de la resina, realización del estratificado, aplicación de la bolsa de vacío, endurecimiento, desmoldeo y postcurado.

\subsection{Preparación del molde}

Consiste en realizar la limpieza del molde y posteriormente aplicar algún tipo desmoldeante, como pueden ser unas ceras o emulsiones de cera. La función de esta etapa es evitar que la pieza quede adherida al molde en el momento del desmoldeo.

\subsection{Preparación del refuerzo}

En esta etapa se debe de cortar el número de capas de refuerzo necesarias, con la geometría y orientación adecuada para que posteriormente de lugar a las dimensiones finales del laminado o estratificado. En nuestro caso serán capas rectangulares de refuerzo de aproximadamente 270x150 mm. Éste es un tamaño adecuado para poder analizar la procesabilidad de la resina sobre el refuerzo y permitirá obtener probetas para los ensayos mecánicos (Figura 1).
Moreover, analyzing these materials systems, the phenolic resin, whose fire behavior is well known but not its mechanical properties, will be compared with two epoxy resins, which are more used composite matrices for structural applications.

\section{DESCRIPTION OF THE COUPON PROCESSING}

Hand impregnation of the reinforcement and compaction by means of vacuum bag (infusion) has been used. This is an open mold process, and therefore only one side of the coupons will present a polished surface finishing.

This method consists of eight steps: mold preparation, fabric cutting, resin formulation, collation, bag application, curing, demolding and postcuring.

\subsection{Mold preparation}

The mold is cleaned and a release agent — such as waxis applied in order to facilitate the demolding step. The release agent is a need due to the fact that the part is usually adhered to the mold after the curing step.

\subsection{Fabric cutting}

This step deals with the cutting of the fabrics needed to complete the laminate, taking account the proper geometry and orientation, so that the dimension and fiber architecture requirements are correctly met. UD carbon $270 \times 150 \mathrm{~mm}$ rectangular shaped fabrics will be cut for the coupon processing, the fibers being oriented in the longitudinal directions (Figure 1). 


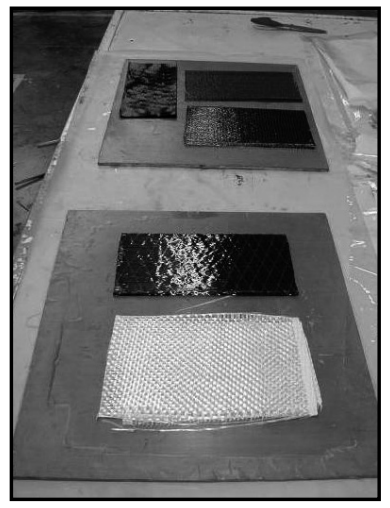

Figura 1. Refuerzo preparado para ser impregnado con la resina. Figure 1. Reinforcement ready for resin impregnation.

\subsection{Preparación de la resina}

La preparación de la resina será función del tipo de resina con el que vamos a trabajar, en el caso de las resinas epoxi, que generalmente son bicomponentes, las cantidades de resina y endurecedor están muy estudiadas para cada resina y no se pueden variar lo más mínimo para no afectar las propiedades finales de la resina endurecida.

Sin embargo en las resinas fenólicas la reacción de polimerización se inicia con la adicción de un catalizador. Se puede jugar con la cantidad de catalizador añadida para obtener mayores o menores tiempos de gel (pot life) o, lo que es lo mismo, el tiempo que se puede trabajar con la resina, sin afectar de forma destacable a las propiedades finales de la resina. Con la resina fenólica (Cellobond J2027L) y el catalizador (Phencat382) que vamos a utilizar nosotros para realizar las pruebas se puede variar el porcentaje en peso de catalizador entre un 3 y un $8 \%$ con relativa seguridad.

\subsection{Realización del estratificado}

El refuerzo seco es impregnado manualmente con la cantidad adecuada de resina, para ello se utilizan brochas y rodillos de impregnación. Se van apilando las diferentes capas de refuerzo hasta conseguir el espesor requerido, regularmente se compactan las capas y se eliminan las burbujas con unos rodillos metálicos preparados para tal efecto (Figura 2).

\subsection{Resin formulation}

Bi-component epoxy resins will be formulated mixing resin and hardener according to the supplier recommendations.

When formulating phenolic resins, the catalyst fraction may vary, so that the get time will be different. In this work, Cellobond J2027L resin and Phencat382 catalyst have been used, the catalyst fraction varying between 3 and $8 \%$.

\subsection{Collation}

The carbon reinforcement is manually impregnated by means of rollers. A number of plies are sequentially piled in order to get the desired laminate thickness. Regularly, the laminate is compacted, so that void content is reduced (Figure 2).

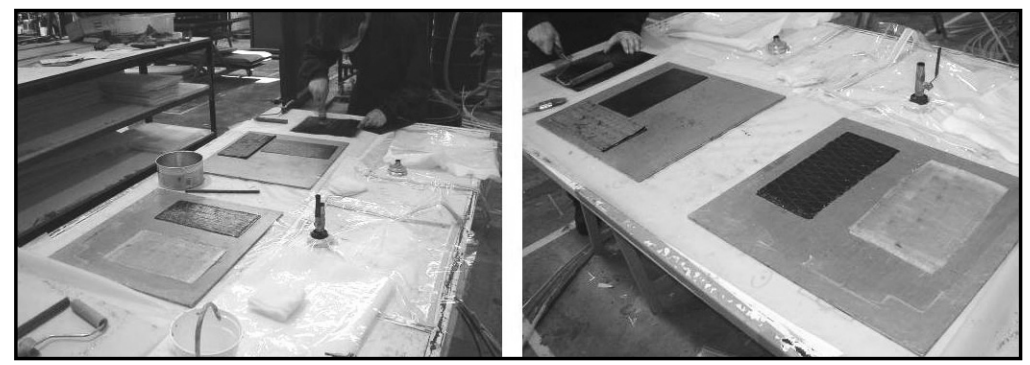

Figura 2. Impregnación, desburbujeo y compactación manual del estratificado.

Figure 2. Impregnation, renoval of entrapped air and hand compaction of the laminate. 


\subsection{Aplicación de la bolsa de vacío}

Una vez que se ha realizado el estratificado se encierra en una bolsa de material plástico que se sella al molde mediante una junta sellante, con el fin de aplicar vacío y conseguir así la eliminación de las burbujas y la compactación del laminado, obteniendo una mejora en las propiedades mecánicas respecto al laminado a mano convencional. A continuación se muestra un esquema (Figura 3 ) en el que se aprecian los elementos que intervienen en este método.

\subsection{Bag application}

Once the laminate is collated, a bag is sealed along the perimeter of the fabric area. Then, vacuum is applied in order to compact the laminate and further reduce the void content. A scheme of this step is represented in Figure 3.

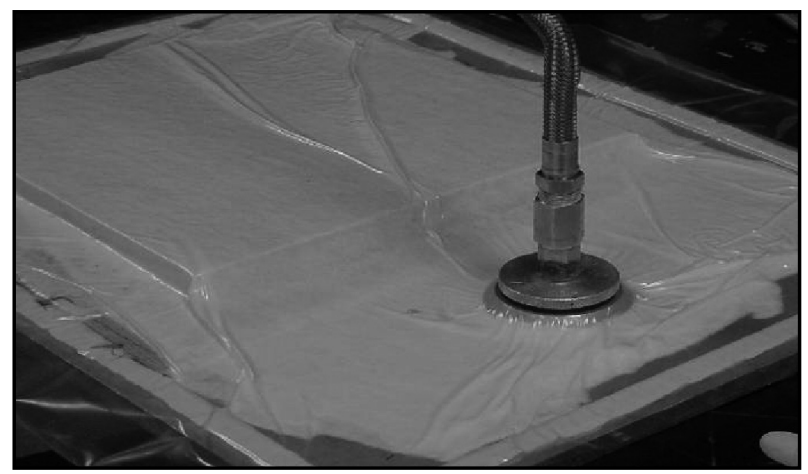

Figura 3. Aplicación de bolsa de vacío para compactación. Figure 3. Application of vacuum bag for compaction.

\subsection{Curado}

Cada tipo de resina en función de su naturaleza tiene una serie de reacciones que producen la reticulación de los diversos componentes y el endurecimiento final de la misma. Este endurecimiento o curado debe llevarse a cabo bajo determinadas condiciones en función del tipo de resina.

En nuestro caso es necesario que la resina fenólica endurezca a una temperatura entre 70 y $80^{\circ} \mathrm{C}$ durante 2 horas. Mientras que las resinas epoxi que utilizamos están formuladas para endurecer a temperatura ambiente, aunque requerirán de tratamientos térmicos posteriores (Figura 4).

\subsection{Curing}

Every type of resin has its own polimerization reaction. This reaction is a function of the resin type and generates the reticulation of the various components and the final curing of the polymer. This curing process must be taken account under the conditions specified for every type of resin.

In our case, the phenolic resin selected cures between 70 and $80^{\circ} \mathrm{C}$ for two hours, meanwhile the epoxy resins used cure at room temperature, though posterior thermal processes are applied (Figure 4).

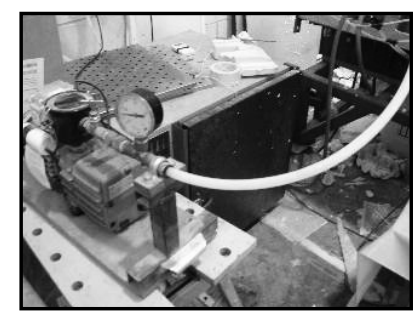

Figura 4. Bomba de vacío y horno de curado de probetas.

Figure 4. Vacuum pump and curing oven.

\subsection{Desmoldeo}

Consiste en la separación de la pieza endurecida del molde, en el caso de una placa plana, como es nuestro caso, no tiene por qué presentar ninguna dificultad, pero sí es

\subsection{Demolding}

This step deals with the separation of the composite material from the mold. If the mold is plane -our case-, 
necesario que uno pueda ayudarse de cuñas para separar la pieza.

Los moldes más complejos están dotados de radios de curvatura y ángulos de desmoldeo que facilitan la extracción de la pieza.

\subsection{Postcurado}

En algunas resinas para conseguir unas propiedades óptimas deben de ser sometidas a una etapa de postcurado después de que hayan endurecido y hayan sido desmoldeadas.

En el caso de la resina fenólica con la que estamos trabajando será necesario introducirla en el horno a una temperatura de $75^{\circ} \mathrm{C}$ durante 2 horas.

La mayoría de las epoxi también requieren de un postcurado, la resina de Gairesa será suficiente introducirla 2 horas a $80^{\circ} \mathrm{C}$, mientras que la suministrada por Axon debe ser sometida inicialmente a una temperatura de $60^{\circ} \mathrm{C}$ durante 1 hora y, posteriormente, a $100^{\circ} \mathrm{C}$ durante 2 horas.

Los laminados con los cuatro refuerzos de carbono presentaron las características mostradas en la Tabla 3. this step does not present any difficulties but tooling may be used if needed.

Complex geometry molds present radii of curvature and demolding angles to facilitate the part extraction.

\subsection{Postcuring}

In order to obtain optima mechanical and fire properties, some resin must be subjected to a post-curing process, after the curing and demolding steps.

In the case of the phenolic resin used in the current study, a post-curing process consisting of an oven cycle at $75^{\circ} \mathrm{C}$ for two hours, will be applied.

Majority of the epoxy resins also need a post-curing process, Gairesa resin was hold at $80^{\circ} \mathrm{C}$ for two hours, while Axon's was hold at $60{ }^{\circ} \mathrm{C}$ for one hour and afterwards at $100^{\circ} \mathrm{C}$ for two hours.

The laminates obtained presented the following properties (Table 3).

Tabla 3 / Table 3

Características de los laminados de fibra de carbono y matrices orgánicas.

Characteristics of the carbon fiber laminates.

\begin{tabular}{|c|c|c|c|c|c|c|}
\hline $\begin{array}{c}\text { Denominación / } \\
\text { Denomination }\end{array}$ & $\%$ Vf & $\begin{array}{c}\text { Gramaje / } \\
\text { Aerial weight } \\
\mathbf{g r / \mathbf { m } ^ { 2 }}\end{array}$ & $\begin{array}{c}\text { Número de capas / } \\
\text { Number of plies }\end{array}$ & $\begin{array}{c}\text { Espesor / } \\
\text { Thickness (mm) } \\
\text { Con / With } \\
\text { Bepox }\end{array}$ & $\begin{array}{c}\text { Espesor / Thickness (mm) } \\
\text { Con / With } \\
\text { Epolam }\end{array}$ & $\begin{array}{c}\text { Espesor / Thickness (mm) } \\
\text { Con / With } \\
\text { Cellobond }\end{array}$ \\
\hline ECC AM & 30 & 250 & 6 & 1.5 & 2.5 & 2.2 \\
\hline ECC MM & 30 & 500 & 4 & 1.4 & 2.2 & 2.0 \\
\hline Hexcel & 30 & 225 & 6 & 1.4 & 2.5 & 2.2 \\
\hline Zoltek & 30 & 300 & 4 & 1.4 & 2.1 & 2.0 \\
\hline
\end{tabular}

En las Figuras 5, 6 y 7 se muestran los laminados con matrices Bepox 1622, Epolam 2500 y Cellobond J2027L.respectivamente.
Figures 5, 6 y 7 represent the Bepox 1622, Epolam 2500and Cellobond J2027L laminates, respectively.



Figura 5. Laminados de carbono elaborados con resina epoxi de Bepox 1622.

Figure 5. Carbon fiber/Bepox 1622 epoxy matrix laminates.

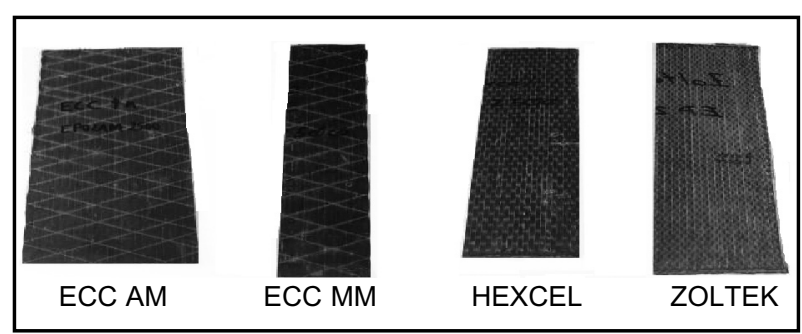

Figura 6. Laminados de carbono elaborados con resina epoxi de AXON (Epolam 2500).

Figure 6. Carbon fiber/AXON, Epolam 2500 epoxy matrix laminates. 




Figura 7. Laminados de fibra de carbono con resina fenólica Cellobond J2027L. Figure 7. Carbon fiber/Cellobond J2027L phenolic matrix laminates.

\section{CARACTERIZACIÓN MECÁNICA DE LOS DIFERENTES SISTEMAS DE MATERIAL}

Se determinaron módulos elásticos y resistencias a tracción siguiendo la norma ISO 9163:2005. Algunas de las probetas se muestran en la Figura 8.

\section{MECHANICAL CHARACTERIZATION OF THE LAMINATES}

Elastic moduli and tensile strengths were obtained by means of ISO 9163:2005. Some coupons are shown in Figure 8.



Figura 8. Fotografía de cuatro probetas con sus tabs.

Figure 8. Pictures of tour tabbled coupons.

\subsection{Resultados de los ensayos mecánicos}

La resistencia de los laminados con las fibras de carbono ECC AM, ECC MM, Hexcel, Zoltek y las tres resinas estudiadas se muestran en las Figuras 9 y 10.

\subsection{Results}

Tensile strengths of laminates composed of ECC AM, ECC MM, Hexcel, Zoltek carbon and the three resins previously mentioned are represented in Figures 9 and 10:

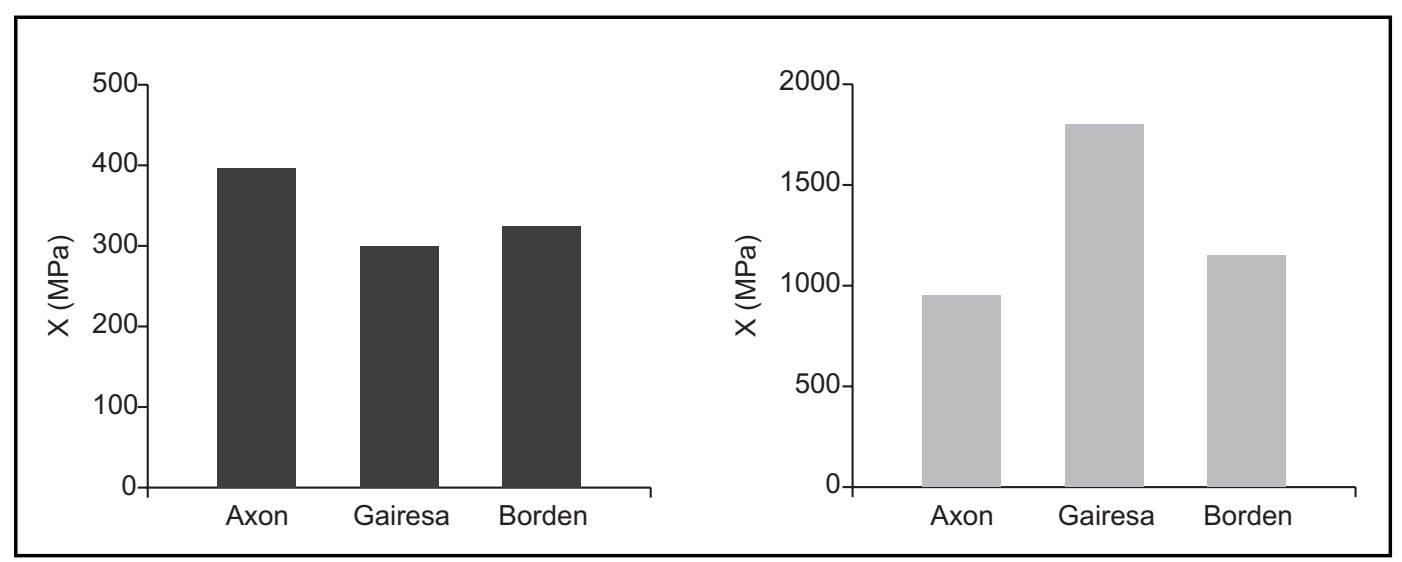

Figura 9. Resistencias para el refuerzo ECC AM (izquierda) y ECC MM (derecha). Figure 9. Tensile strengths for ECC AM (left) and ECC MM (right).

Las resistencias más elevadas se obtuvieron con fibras de carbón de módulo medio ECC MM, Excel y Zoltek mientras que se registraron valores muy inferiores para
The highest tensile strengths were reported for ECC MM, Excel and Zoltek, while the high modulus carbon fiber material gave the lowest results, as expected: high 




Figura10. Resistencias para el refuerzo Hexcel (izquierda) y Zoltek (derecha). Figure 10. Tensile strengths for Excel (left) and Zoltek (right).

el carbono de alto módulo. Es lógico que así sea ya que las fibras de alto módulo se caracterizan por tener alta rigidez pero baja resistencia. Centrándonos en los resultados de las probetas con fibra de carbono de módulo medio, las probetas que contenían la matriz Bepox (epoxi) es la que mayores resistencias dio. Hay que subrayar que esta matriz combinada con el refuerzo de ECC MM dio una resistencia de $1.800 \mathrm{MPa}$, prácticamente un orden de magnitud superior a la resistencia de un acero convencional cuya resistencia está en torno a $200 \mathrm{MPa}$. En todos los casos la matriz fenólica dio valores muy inferiores a los obtenidos para la matriz epoxídica Bepox.

Los módulos de Young para los refuerzos ECC AM, ECC MM, Hexcel, Zoltek y las tres resinas estudiadas se muestran en las Figuras 11 y 12: modulus carbon fibers are characterized by presenting high elastic modulus but los tensile strength. Focussing on medium modulus carbon fiber coupons, the epoxy Bepox laminate was the highest among the three matrices analyzed. It must be emphasized that this matrix along ECC MM carbon fiber gave a tensile strength of $1800 \mathrm{MPa}$ was reported for Bepox epoxy matrix along ECC MM carbon fiber, almost an order of magnitude higher than standard steel. Phenolic matrix laminate gave lower strengths than Bepox epoxy in all the cases.

Young module for ECC AM, ECC MM, Hexcel, Zoltek carbon fibers and the three matrices analyzed are represented in Figures 11 and 12.

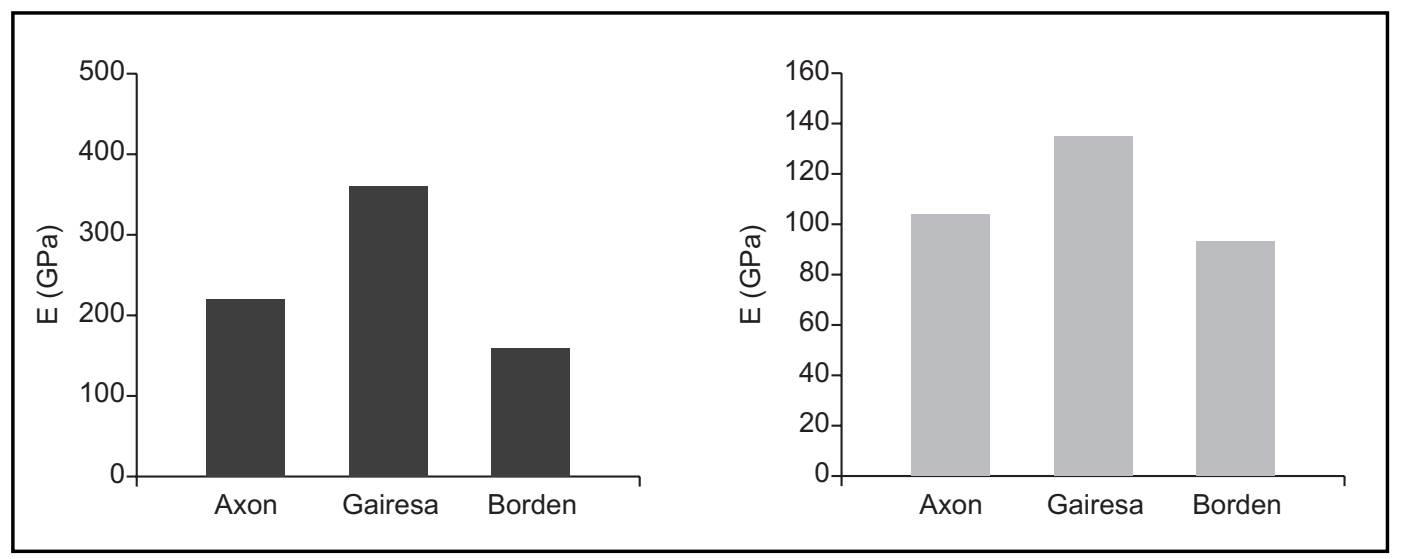

Figura 11. Módulos de Young para el refuerzo ECC AM (izquierda) y ECC MM (derecha). Figure 11. Young moduli for ECC AM (left) and ECC MM (right).

Como cabía esperar, los mayores módulos se obtuvieron para la fibra de alto módulo (ECC AM). Este refuerzo combinado con la matriz de epoxi Bepox dio un módulo de $380 \mathrm{GPa}$, es decir, casi el doble que el acero (210
The highest longitudinal elastic modulus was reported for the high modulus ECC AM carbon fiber, as expected. This reinforcement along with Bepox epoxy gave a Young modulus of $380 \mathrm{GPa}$, almost double than standard 




Figura 12. Módulos de Young para el refuerzo Excel (izquierda) y Zoltek (derecha). Figure 12. Young moduli for Excel (left) and Zoltek (right).

$\mathrm{GPa}$ ). La matriz fenólica dio un valor muy inferior, 140 GPa. Para el resto de refuerzos, una vez más, la matriz epoxídica Bepox es la que dio mayores valores: 135, 110 y 93 GPa para EC MM, Excel y Zoltek respectivamente. En los tres casos, el módulo es muy inferior al del acero. Con objeto de salvar esta diferencia en rigidez, se suele acudir a configuraciones tipo sándwich.

\subsection{Morfologías de fallo}

Los modos de fallo observados son los comunes en este tipo de materiales reforzados con tejidos unidireccionales. Se puede apreciar en las siguientes imágenes el tipo de fractura que se produce (Figuras 13,14 y 15). steel (210 GPa). Phenolic matrix gave a lower value (140 $\mathrm{GPa})$. For the rest of reinforcements, Bepox epoxy was once more the leading material, with moduli values 135 , 110 and 93 GPa for EC MM, Excel and Zoltek respectively. In the three cases, the elastic moduli are much lower than steel. In order to overcome this stiffness drawback, sandwich materials are currently applied for components subjected to bending or buckling.

\subsection{Failure morphologies}

Failure modes oberved were the typical for UD carbon fabric composite materials. A local failure occurs and the crack propagates longitudinally up to the tabbed areas (explosion failure). Figures 13, 14 and 15 represent some failed coupons.

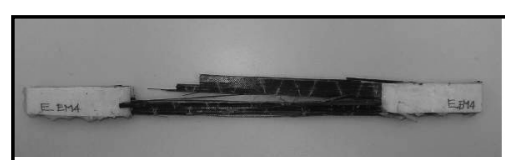

Carbono / Carbon ECC MM



Carbono / Carbon ZOLTEK

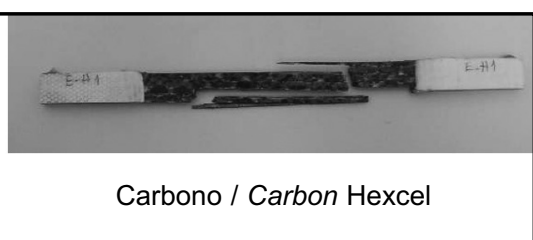

Carbono / Carbon Hexcel

Figura13. Modo de fallo de resina de epoxi Epolam 2500 con diferentes refuerzos.

Figure 13. Failure mode of epoxy Epolam 2500 epoxy with different reinforcements.



Figura 14. Modo de fallo de resina de epoxi Bepox 1622 con carbono diferentes refuerzos. Figure 14. Failure mode of Bepox 1622 epoxy with different reinforcements. 


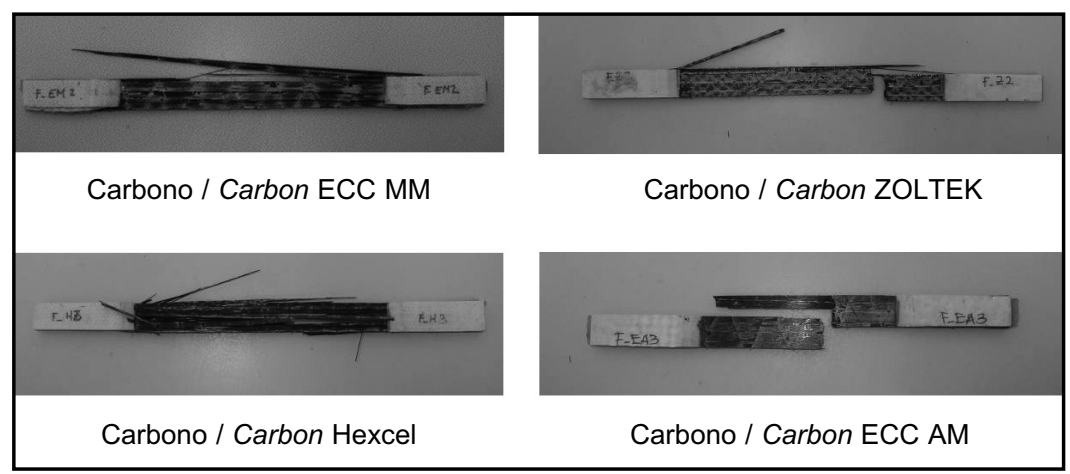

Figura 15. Modo de fallo de resina fenólica Cellobond J2027L con carbono ECC MM. Figure 15. Failure mode of phenolic Cellobond J2027L with ECC MM carbon.

\section{CONCLUSIONES}

Se han analizado doce sistemas de materiales compuestos formados por tres matrices orgánicas:

- Gairesa, Bepox 1622

- Axon, Epolam 2500

- Borden, Cellobond J2027L

Y cuatro refuerzos de fibra de carbono:

- Zoltek , PX35FBUD0300

- Excel, UD 250

- ECC MM, UD 45002

- ECC AM, UD 82502

Se fabricaron probetas mediante el proceso de infusión y se caracterizaron a tracción siguiendo la norma ISO 9163:2005.

Las resistencias más elevadas se obtuvieron con fibras de carbón de módulo medio ECC MM, Excel y Zoltek mientras que se registraron valores muy inferiores para el carbono de alto módulo. Es lógico que así sea ya que las fibras de alto módulo se caracterizan por tener alta rigidez pero baja resistencia. Centrándonos en los resultados de las probetas con fibra de carbono de módulo medio, las probetas que contenían la matriz Bepox (epoxi) es la que mayores resistencias dio. Hay que subrayar que esta matriz combinada con el refuerzo de ECC MM dio una resistencia de $1.800 \mathrm{MPa}$, prácticamente un orden de magnitud superior a la resistencia de un acero convencional cuya resistencia está en torno a $200 \mathrm{MPa}$. En todos los casos la matriz fenólica dio valores muy inferiores a los obtenidos para la matriz epoxídica Bepox.

Como cabía esperar, los mayores módulos elásticos se obtuvieron para la fibra de alto módulo (ECC AM). Este refuerzo combinado con la matriz de epoxi Bepox dio un módulo de $380 \mathrm{GPa}$, es decir, casi el doble que el acero (210 GPa). La matriz fenólica dio un valor muy inferior,

\section{CONCLUSIONS}

Twelve composite material systems have been analyzed. The matrices used are:

- Gairesa, Bepox 1622

- Axon, Epolam 2500

- Borden, Cellobond J2027L

And he carbon fiber reinforcements are:

- Zoltek, PX35FBUD0300

- Excel, UD 250

- ECC MM, UD 45002

- $E C C A M, U D 82502$

Coupons were fabricated by means of the infusion process and experimentally analyzed by means of tensile tests according to ISO 9163:2005.

The highest tensile strengths were reported for ECC MM, Excel and Zoltek, while the high modulus carbon fiber material gave the lowest results, as expected. Epoxy Bepox laminate was the highest among the three matrices analyzed gave a tensile strength of $1800 \mathrm{MPa}$ was reported for Bepox epoxy matrix along ECC MM carbon fiber, almost an order of magnitude higher than standard steel. Phenolic matrix laminate gave lower strengths than Bepox epoxy in all the cases.

The highest longitudinal elastic modulus was reported for the high modulus ECC AM carbon fiber, as expected. This reinforcement along with Bepox epoxy gave a Young modulus of $380 \mathrm{GPa}$, almost double than standard steel (210 GPa). Phenolic matrix gave a lower value (140 
140 GPa. Para el resto de refuerzos, una vez más, la matriz epoxídica Bepox es la que dio mayores valores: 135, 110 y 93 GPa para EC MM, Excel y Zoltek, respectivamente. En los tres casos, el módulo es muy inferior al del acero. Con objeto de salvar esta diferencia en rigidez, se suele acudir a configuraciones tipo sándwich.

La principal conclusión de este estudio es que es posible obtener materiales compuestos con matriz orgánica resistentes a fuego/humos con elevadas prestaciones mecánicas, tanto en resistencia a tracción como en módulo elástico.
GPa). For the rest of reinforcements, Bepox epoxy was once more the leading material, with module values 135, 110 and 93 GPa for EC MM, Excel y Zoltek respectively. In the three cases, the elastic module are much lower than steel. In order to overcome this stiffness drawback, sandwich materials are currently applied for components subjected to bending or buckling.

A main conclusion of this study is that it is possible to obtain fire/smoke resistant composite materials with high mechanical performance in terms of both, tensile strength and elastic modulus.

\section{BIBLIOGRAFÍA / BIBLIOGRAPHY}

(1) Knop, A.; Scheib, W.: Chemistry and Application of Phenolic Resins. Berlin: Springer-Verlag (1979).

(2) Hunter, J.; Forsdyke, K. L.: Phenolic glass fiber-reinforced plastic and its recent applications. Polym Compos (1989); 2: 169185.

(3) Sorathia, U.; Dapp, T.; Ker,r J.: "Flammability characteristics of composites for shipboard and submarine internal applications". Proc 36th Int SAMPE Symp, CA (1991); 1868-1878.

(4) Sevart, J. L.; Griffin, O. H.; Gurdal, Z.; Warner, G.: "Flammability and toxicity of materials for marine vehicles". Naval Eng J (1990); 45-54. doi:10.1111/j.1559-3584.1990.tb00899.x

(5) Tewarson, A.; Macaione, D. P.: "Polymers and composites-an examination of fire spread and generation of heat and fire products". J Fire Sci (1993); 11: 421-41. doi:10.1177/073490419301100504

(6) Mouritz, A. P.; Mathys, Z. and Gibson, A. G.: "Heat release of polymer composites in fire". Composites Part A (2006), vol. 37 (7): 1040-1054.

(7) Sorathia, U.; Lyon, R.; Ohlemiller, T.; Griener, A.: "A review of fire test methods and criteria for composites". SAMPE J (1997); 33: 23-31.

(8) Babrauskas, V.: "The cone calorimeter". In: DiNenno, P. J.; Drysdale, D.; Beyler, C. L.; Walton, W. D.; Custer, R. L. P.; Hall, J. R.; Watts, J. M.; editors. SFPE Handbook of Fire Protection Engineering. Bethesda, Maryland: Society of Fire Protection Engineers (2002), pp. 3-63, pp. 3-81.

(9) Brown, J. R.; St John, N. A.: "Fire-retardant low-temperature-cured phenolic resins and composites". TRIP (1996); 4: 416-420.

(10) Hshieh, F. Y; Beeson, D.: "Flammability testing of flame-retarded epoxy composites and phenolic composites". Fire Mater (1997); 21: 41-49. doi:10.1002/(SICI)1099-1018(199701)21:1<41::AID-FAM595>3.0.CO;2-G

(11) Coneas, J. A.; Marcilla, A.; Font, R.; Caballero, J. A.: "Thermogravimetric studies on the thermal decomposition of polyethylene". J Anal Appl Pyrolysis (1996); 36: 1-15. doi:10.1016/0165-2370(95)00917-5

(12) Regnier, N.; Mortaigne, B.: "Analysis by pyrolysis/gas chromatograhy/- mass spectrometry of glass fibre/vinylester thermal degradation products". Polym Degrad Stability (1995); 49: 419-428.

(13) Bourbigot, S.; Flambard, X.; Poutch, F.: "Study of the thermal degradation of high performance fibres-application to polybenzazole and p-aramid fibres". Polym Stability Degrad (2001); 74: 283-290.

(14) Bansal, R. J.; Mittal, J.; Singh, P.: "Thermal stability and degradation studies of polyester resins". J Appl Polym Sci (1989); 37: 1901-1908. doi:10.1002/app.1989.070370713

(15) Vogt, J.: "Thermal analysis of epoxy-resins: identification of decomposition products". Thermochim Acta (1985); 85: 407-410. doi:10.1016/0040-6031(85)85611-2

(16) Arii, T.; Ichihara, S.; Nakagawa, H.; Fujii, N.: "A kinetic study of the thermal decomposition of polyesters by controlled-rate thermogravimetry". Thermochim Acta (1998); 319: 139-149. doi:10.1016/S0040-6031(98)00414-6

(17) Babrauskas, V.; Peacock, R. D.: "Heat release rate: the single most important variable in fire hazard". Fire Safety J (1992);

18: 255-272. doi:10.1016/0379-7112(92)90019-9

(18) Babrauskas, V.: "Why was the fire so big? HHR: The role of heat release rate in described fires". Fire Arson Investig (1997); 47: 54-57.

(19) Babrauskas, V.: "The generation of CO in bench-scale fire tests and the prediction for real-scale fires". Proc Int Conf Fire Mater (1992); 155-177.

(20) Brown, J. E.; Braun, E.; Twilley, W. H.: "Cone Calorimeter Evaluation of the Flammability of Composite Materials". NBSIR (1988), 88-3733. 
(21) Hume, J.: "Assessing the fire performance characteristics of GRP composites". Int Conf Mater Des Against Fire, London (1992); 11-15.

(22) Sorathia, U.: "Flammability and fire safety of composite materials". Proceedings of the 1st International Workshop on Composite Materials for Offshore Operations, Houston, Texas, 26-28 oct. (1993), pp. 309-317.

(23) Egglestone, G. T.; Turley, D. M.: "Flammability of GRP for use in ship superstructures". Fire Mater (1994); 18: 255-260. doi:10.1002/fam.810180408

(24) Scudamore, M. J.: "Fire performance studies on glass-reinforced plastic laminates". Fire Mater (1994); 18: 313-325. doi:10.1002/fam.810180507

(25) Brown, J. R.; Fawell, P. D.; Mathys, Z.: "Fire-hazard assessment of extendedchain polyethylene and aramid composites by cone calorimetry". Fire Mater (1994); 18: 167-172. doi:10.1002/fam.810180304

(26) Gibson, A. G.; Hume, J.: "Fire performance of composite panels for large marine structures". Plastics, Rubbers Compos Proc Applic (1995); 23: 175-83.

(27) Ohlemiller, T. J.; Cleary, T. G.: Upward flame spread on composite materials Fire and Polymers II: American Chemical Society (1995).

(28) Brown, J. R.; Mathys, Z.: "Reinforcement and matrix effects on the combustion properties of glass reinforced polymer composites". Composites (1997); 28A: 675-681.

(29) Sastri, S. B.; Armistead, J. P.; Keller, T. M.; Sorathia U.: "Flammability characteristics of phthalonitrile composites". Proceedings of the 42th International SAMPE Symposium 1997; May 4-8: 1032-1038.

(30) Le Bras, M.; Bourbigot, S.; Mortaigne, B.; Cordellier, G.: "Comparative study of the fire behaviour of glass-fibre reinforced unsaturated polyesters using a cone calorimeter". Polym Polym Compos (1998); 6: 535-539.

(31) Lin, B.: "Cyanate esters with improved fire resistance". Proc 44th Int SAMPE Symp 1999; 23-27: 1424-1430.

(32) Sorathia, U.; Gracik, T.; Ness, J.; Blum, M.; Le, A.; Scholl, B.; Long, G.: "Fire safety of marine composites". Proc 8th Int Conf Marine Applic. Compos. Mater.; 14-16 March, Florida (2000).

(33) Koo, J. H.; Muskopf, B.; Venumbaka, S.; Van Dine, R.; Spencer, B.; Sorathia, U.: "Flammability properties of polymer composites for marine applications". Proceedings of the 32nd International SAMPE Technical Conference (2000); 5-9: 136. 